\title{
Building a System Dynamics Model to Achieve Optimal Economic Efficiency of Groundwater Use, Case Study: Wadi Al-Dawasir, Saudi Arabia
}

\author{
Abdulaziz M. Alqarawy, Ahmed S. Kamis, Jalal M. BaSahi and Mohammed I. Al Saud* \\ Department of Hydrology and Water Resources Management, Faculty of Meteorology, \\ Environment and Arid Land Agriculture, King Abdulaziz University, Jeddah, and *Ministry of \\ Environment, Water and Agriculture, Saudi Arabia \\ alqarawy86@gmail.com
}

\begin{abstract}
An agricultural hydro-economic System Dynamics model is built to study optimal solutions for economic efficiency of groundwater use and to achieve water and food sustainability in Wadi Al-Dawasir. Seven scenarios are proposed for the period (2017-2030). These scenarios are designed to study the anticipated effects of the government's decision to stop growing fodder crops by 2019. The results showed that the implementation of this decision would reduce the cumulative depletion of water by 21 billion $\mathrm{m} 3$. In addition, the transfer from fodder to vegetable farming is the least water consuming and offers higher value agricultural products than other scenarios.
\end{abstract}

Keywords. System Dynamics, Wadi Al-Dawasir, irrigation cost, Groundwater value.

\section{Introduction}

Although the Kingdom Saudi Arabia is an energy resources rich country, it is considered as poor in regard of water resources, whereas the Kingdom is located in an arid region with an average annual rainfall of less than $100 \mathrm{~mm}$. The Kingdom of Saudi Arabia occupies an area of approximately 2.15 million $\mathrm{km}^{2}$ and having population of 31 million. Over the past three decades, Saudi Arabia has witnessed a comprehensive development in all sectors. This has created an unprecedented increase of water consumption, both in the agricultural and urban sectors causing a challenge represented in the scarcity of fresh water in the Kingdom (Ouda, 2013).The total water consumption in Saudi Arabia is estimated at 24 billion cubic meters per year. Urban consumption (municipal and industrial) sector accounts for $17 \%$ of total demand while the agricultural sector accounts for $83 \%$ of the total water demand in Saudi Arabia (Alhassan et al., 2015).

The water consumption of the agricultural sector depends on renewable and nonrenewable groundwater without restrictions governing efficient use of water. Whereas the cost of water borne by farmers barely exceeds the price of energy needed to pump water out of the ground, the prices of energy provided to farmers are heavily subsidized by the government, which makes the cost of water in the agricultural sector very low allowing no incentive for farmers to invest in water conservation and water use efficiency in crop production (such as agricultural reserves and drip irrigation systems). Due to the vast area of the Kingdom of Saudi Arabia and the different geographical, climatic, geological and hydrological conditions and the different agricultural and demographic circumstances, 
Wadi Al-Dawasir governorate is selected as a case study because it is an agriculture dominated area that is served from non renewable groundwater aquifers almost exclusive to the area. However, the model has been designed to be applicable on any other region of the Kingdom of Saudi Arabia.

Wadi Al-Dawasir has been selected in view of the fact that it is one of the major irrigation water abstraction fed from Al-Wajid confined aquifer (Non-renewable groundwater). Agricultural systems in the Wadi Al-Dawasir area consists of technically highly developed farm enterprises that operate modern pivot irrigation system. The size of the center pivot ranges from 30 to 60 ha with farms managing hundreds of them with the corresponding number of wells (Elhag and Bahrawi, 2017). In addition to the fact that Wadi Al-Dawasir is located about 650 meters above the sea level east of Asir plateau and overlooks the northwestern edge of the Rub' al Khali desert (The empty quarter), which makes the supply of desalinated water (the alternative product of groundwater) very expensive (Gesellschaft and Dornier, 2010 b).

The agricultural operations were spread on an extensive area, using high-capacity pumps for the irrigation of crops, the most important of which being fodder crops using axial irrigation technology. Consequently, the decline in the groundwater level in 2005 was estimated by the formation of a cone depression of 150 meters in depth and $100 \mathrm{~km}$. in diameter. Till to date, the availability and accessibility of groundwater is not considered as a limiting factor to be taken into consideration while adopting pumping operations in this area. Instead, agricultural development is subject to policy change. Wheat subsidy had been the driving force behind the development of pumping operations that began in the early 1980 s and after the implementation of the cessation of subsidy in 1993, wheat cultivated areas declined by $73 \%$ in just two years. Thus, the cessation of subsidies should have contributed to the reduction of groundwater pumping practices. But the goal has not yet been achieved. Agricultural production has converted from wheat towards fodder crops which has created higher demand for much water quantities. Wadi Al-Dawasir area is experiencing a heavy water pumping exceeding the demands in the 1990s when wheat cultivation was at its peak (Gesellschaft and Dornier, 2010 a).

The objective of this paper is to build a System dynamic modeling for Wadi AlDawasir region in the Kingdom of Saudi Arabia, such model shall be adaptable and applicable to the different regions of Saudi Arabia and other arid regions. The model will be appropriate to simulate the different scenarios imposed by the user or the decision maker in order to estimate the annual consumption of groundwater by the agricultural sector for each scenario and to estimate the savings or water deficit resulting from the application of each scenario and to study the economic dimension resulting therefrom and study the effect of the transformation of water used in each scenario from the agricultural sector to the residential sector.

\section{Methods and Materials}

The methodology of the study was based on the building of a System Dynamic Modelling to search for optimal solutions towards achieving economic efficiency of the use of groundwater in Wadi Al-Dawasir area in Saudi Arabia to achieve water and food sustainability through the use of simulation and analysis program (Stella Software), Through which the researcher has built a model to simulate several scenarios (each 
scenario carries a different package of water, economic and agricultural arrangements.

The model will estimate the following variables (for each scenario and for each crop and for each year for the study period 20172030): Simulation of agricultural areas, estimation of irrigation water quantity, estimating the total cost paid by farmers for obtaining the groundwater for irrigation, estimation of the cost of groundwater alternative source used in irrigation, estimation of the effect of the transfer of groundwater to the residential sector, estimation of the market value of agricultural products, estimation of the total costs of each crop, estimation of the farmers' annual profits, estimation of the of the annual income of trade intermediaries.

Subsequently, the economic dimension of the transformation of water savings (resulting from the application of each scenario compared to the current situation) to the urban sector through the results provided by the model is studied. The results of these models will enable the regulators of the water and agricultural sector in Saudi Arabia to identify the appropriate systemization to raise the economic efficiency of the use of groundwater in Saudi Arabia. The model is also capable of modifying the values of variables in the future to be a measuring tool that simulates the effects, which may result from any proposed water regulations before adopting.

\subsection{System Dynamics}

System dynamics (SD) developed during the late $1950 \mathrm{~s}$ by Forrester at the Massachusetts Institute of Technology (Forrester, 1961). Over the last 50 years, SD applications in water resources management have branched in many directions such as regional analysis, river basin planning, urban water, flooding, irrigation and pure process models (Zhi, et al. 2018).
The System Dynamic Modeling is a sophisticated methodological tool used to describe the behavior of the system by means of Causal Loop Diagram or "stock and flow Diagrams" to form the dynamic system for use in the applications for which it is built. The system dynamic modeling designed on the system thinking style is a well-established methodology for measuring complex feedback in the system interactions. The system dynamic modeling is made up of the stock which is a calculator of the components of the system either spatially or temporally and the system contains the flow path where the flow rate is directed either inside or outside the system's stock, The system also contains converters that change the rates and units. All these components are assembled and logically installed to simulate the dynamic processes of the system. Most of the dynamic systems applications implemented by computer simulations were based on the use of a package of software such as (Vensim) and (Stella) (Cheng et al. 2011).

System dynamic is a methodology used to study and manage complex systems that change as time changes using several components such as stocks, flows, converters, connectors, internal feedback loops, the system also contains tools to control the time and methods of entering and displaying data. By linking these components in a scientific manner and based on correct information we shall have a system dynamic that simulates the problem that we actually want to tackle. The researcher or decision maker can tell how much each variable affects other variables and the entire system dynamic. The effect of the time dimension on all variables can also be identified. Dynamic Simulation System enables the decision maker or researcher to study the problem in several scenarios so that the system responds to the input of each scenario in an instantaneous way to show the 
decision maker or researcher the dimensions of each scenario separately. The system has the potential to develop in the future and it is customizable and accessible for data entry in a manner to simulate reality and change the effects surrounding the problem in the future. There are many programs that can be used to implement the system dynamic and the most famous of these programs are (Stella) and (Vensim) (Ford, 2010). The researcher has used (Stella) program for being characterized by better specifications than others based on the experiences of the researcher.

\subsection{Data Collection}

Random and stratified sample method is used to collect data. Taking into account samples suitability with the crop categories (stratified distribution of the samples), so that the samples number will not be less than 30 samples (Abdelfattah, 2013). A field survey covering 39 farms in Wadi Al-Dawasir area, included alfalfa farms, other fodder crops, dates, vegetables and wheat has been conducted. Agricultural crops were divided into five categories, so that the class distribution of the questionnaires commensurate with the percentage of the agricultural area for each crop category in the study area in accordance with to the latest statistics of the Ministry of Environment, Water and Agriculture, which indicated that the agricultural area in Wadi Al-Dawaser area is composed of alfalfa farms which represents $47 \%$ of the cultivated lands in study area, the other fodders category represents $35 \%$, date category $9 \%$, vegetable category $6 \%$, wheat category $3 \%$ of the cultivated lands in the study area (Ministry of Environment, Water and Agriculture, 2013).

A survey questionnaire was prepared for the field survey and it included the following information: (name of the farmer, means of communication, farm site, farm area, age of agricultural investment, average annual production of the farm, number of harvesting times in summer and winter, cost of well construction, cost of purchase of generators and pumps used for pumping ground water, the life span of generators and pumps used for groundwater pumping, type of irrigation system, cost of irrigation system construction, irrigation system life span, average annual maintenance cost, average annual labor cost, average annual cost for harvesting equipment, average annual cost of seed purchase, average annual cost of fertilizer purchase, average annual cost of insecticide spraying, annual cost of agricultural land lease, average annual farmer's profit, average annual income of brokers, type of fuel used to operate on-farm generators, average amount of fuel consumed on the farm, the price paid by farms for fuel). The researchers assumed that the average artesian well life and life span of generators, pumps and irrigation systems is 20 years (based on the opinion of an agricultural expert in the study area).

- The LandSat- 8 satellite image was analyzed and the researchers used the ENVI program for estimating (NDVI) for each pixel of an image and then the ArcMap program was used to estimate the cultivated lands areas in Wadi Al-Dawasir region, which has been estimated at 124,698 hectares for the year 2017 (Fig. 1). (Assuming that this area represents the cultivated area throughout the year) (Canada Center for Remote Sensing, 2015).

The most important agricultural crops in the study based on the latest statistical publication issued by the Ministry of Environment, Water and Agriculture in 2013 has been evaluated (Ministry of Environment, Water and Agriculture, 2013).

The potential annual evapotranspiration (ET) (The FAO Penman-Monteith method 1998) was estimated in Wadi Al-Dawasir at 
$2628 \mathrm{~mm} \mathrm{/} \mathrm{year.} \mathrm{The} \mathrm{evapotranspiration}$ ranges between $4.6 \mathrm{~mm} /$ day in winter and 9.1 $\mathrm{mm} /$ day in the summer. The average water use information for each crop and the water requirement for each crop in the study area were estimated by calculating the evapotranspiration rate - the referential for each crop $\left(\mathrm{ET}_{0}\right)$ using meteorological information and the Penman-Monteith formula (Gesellschaft and Dornier, 2010 b).

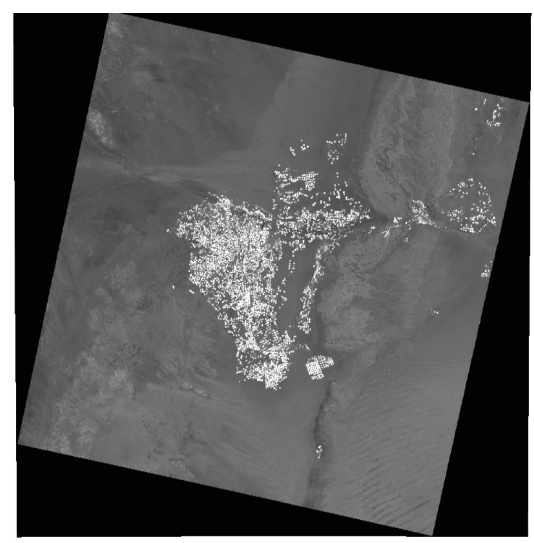

Fig. 1. An image showing the variations in vegetation cover (NDVI) of the LandSat satellite image of Wadi AlDawasir region (LANDSAT-8).

\subsection{Building the System Dynamic Modeling}

The dynamic system modeling was built passing through 11 Phases (Fig. 2), Each phase contains stocks and converters that include the variables (inputs and outputs), these variables are linked to the time dimension through the use of flows, and the mathematical linkage between all variables, both within the same stage or with variables in other stages through the connectors. The system also contains tools for time control and data entry and presentation methods. Figure 3 illustrates the structure of the system dynamic model that was built using the STELLA program.

\subsection{Building of a System Dynamic Modeling Interface}

The interface of the system dynamic modeling is designed so that the use of the model becomes easy and obvious for all users. The interface is divided into 16 display and entry slides and a user can easily navigate around. Figure 4 shows the main slide of the model interface, the model also contains an information entry slide for each crop where Fig. 5 shows a sample of one of the crop slides, and the rest of the slides are used to display the results of the model. Figure (6) represents a model for one of the results display models.

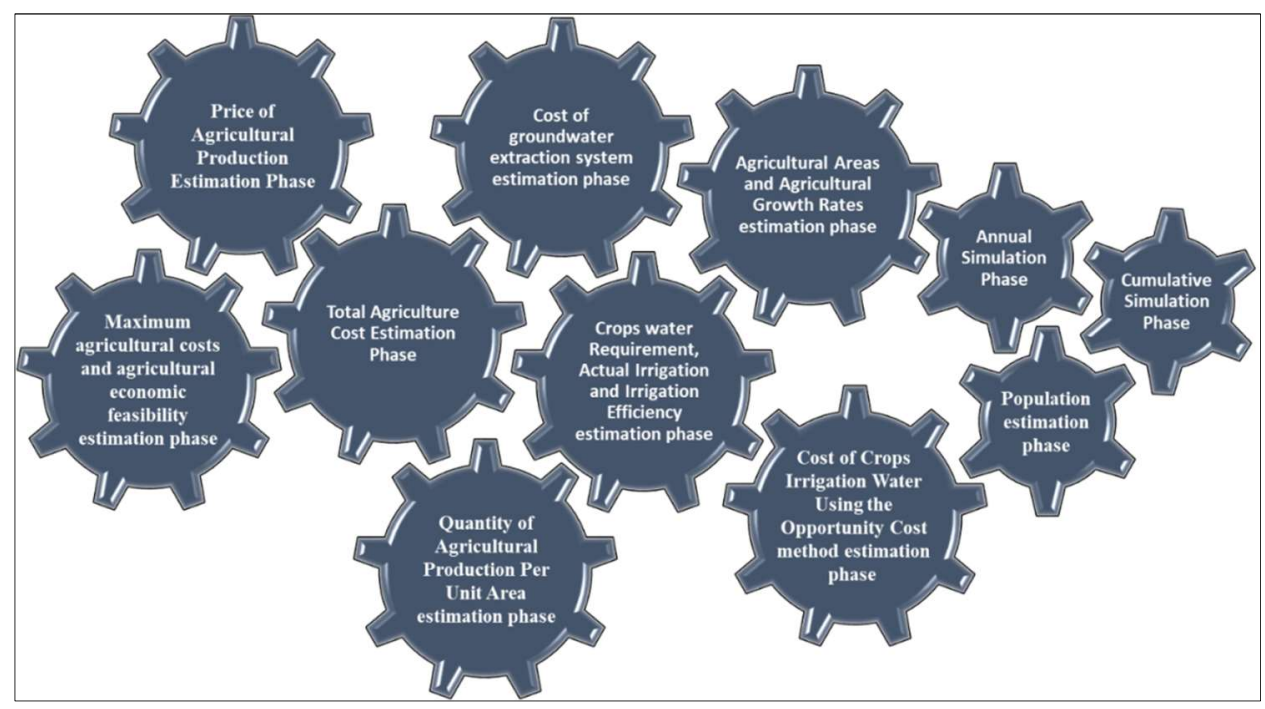

Fig. 2. The stages of building the system dynamic modeling. 


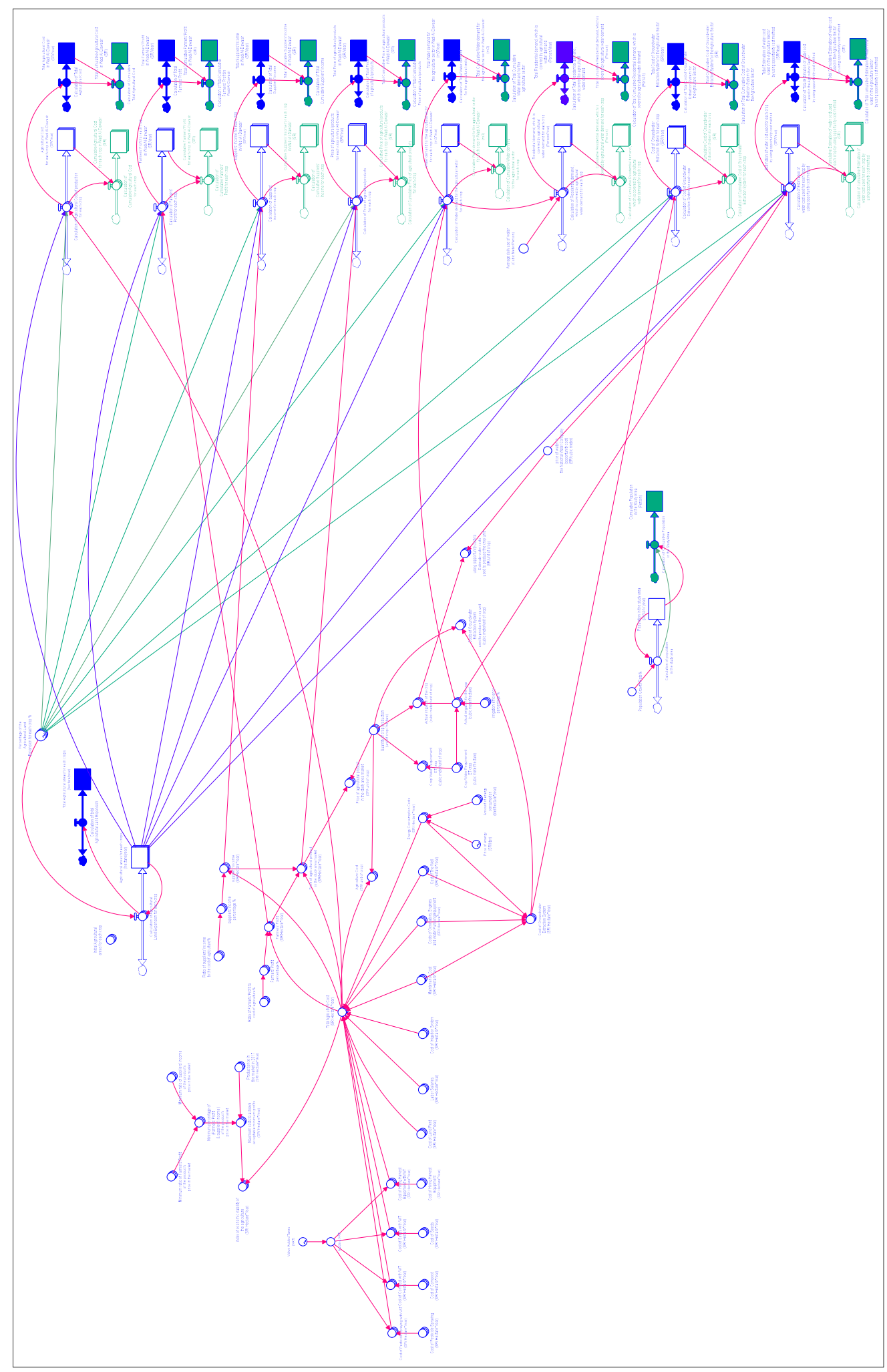

Fig. 3. System dynamic structure. 


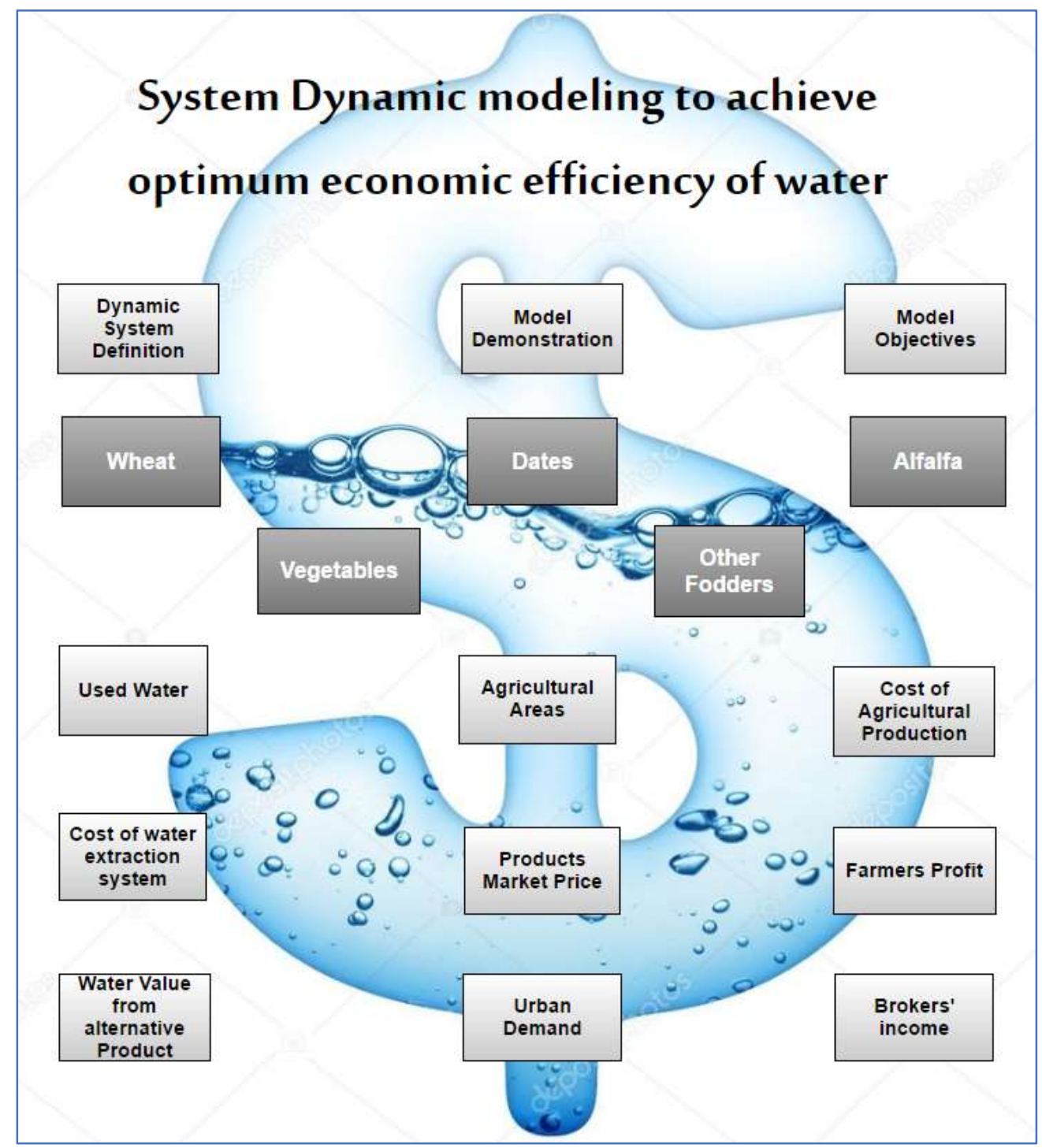

Fig. 4. The main interface slide of the dynamic system modeling interface. 


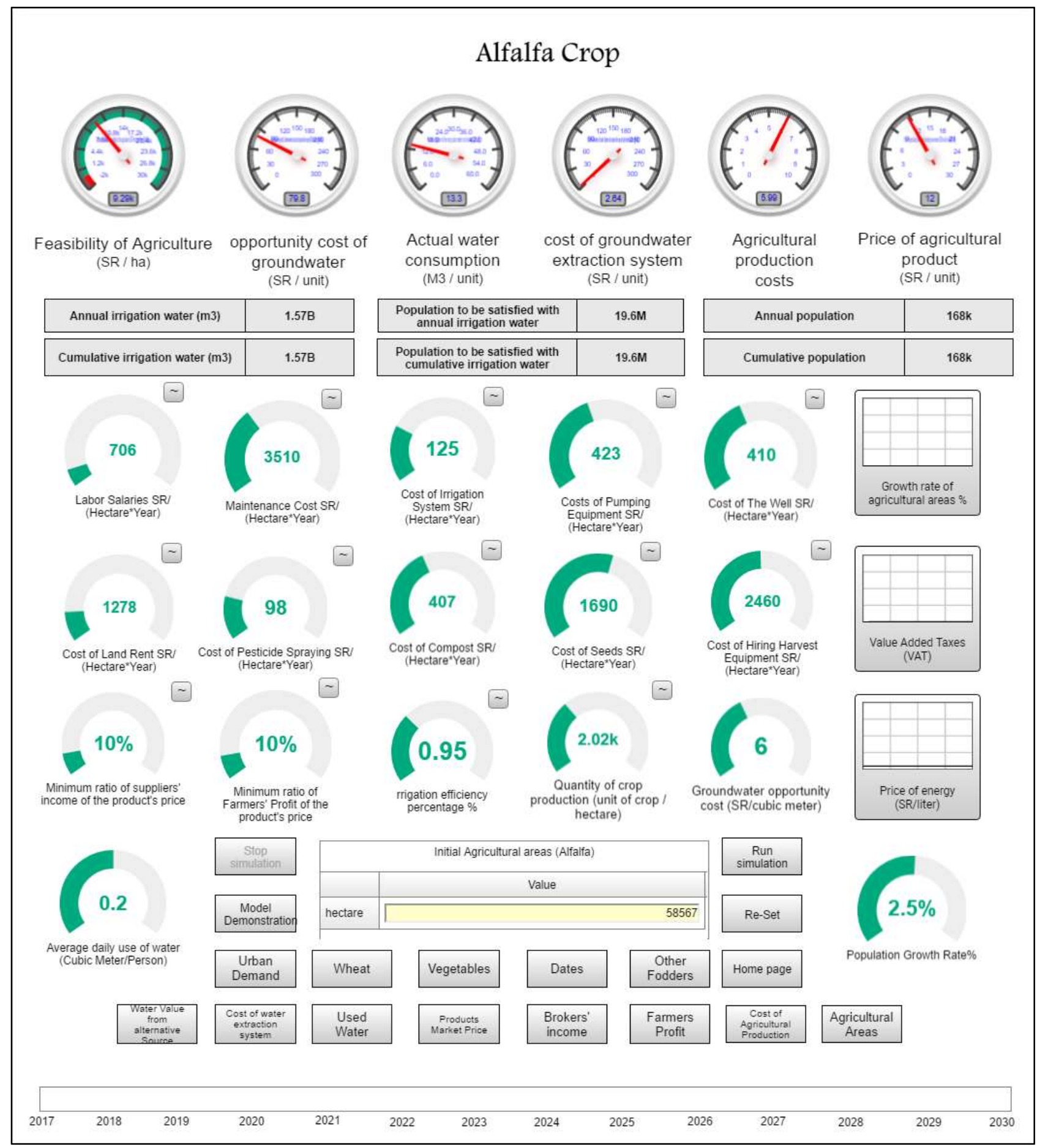

Fig. 5. Alfalfa crop slide in the system dynamic modeling interface. 


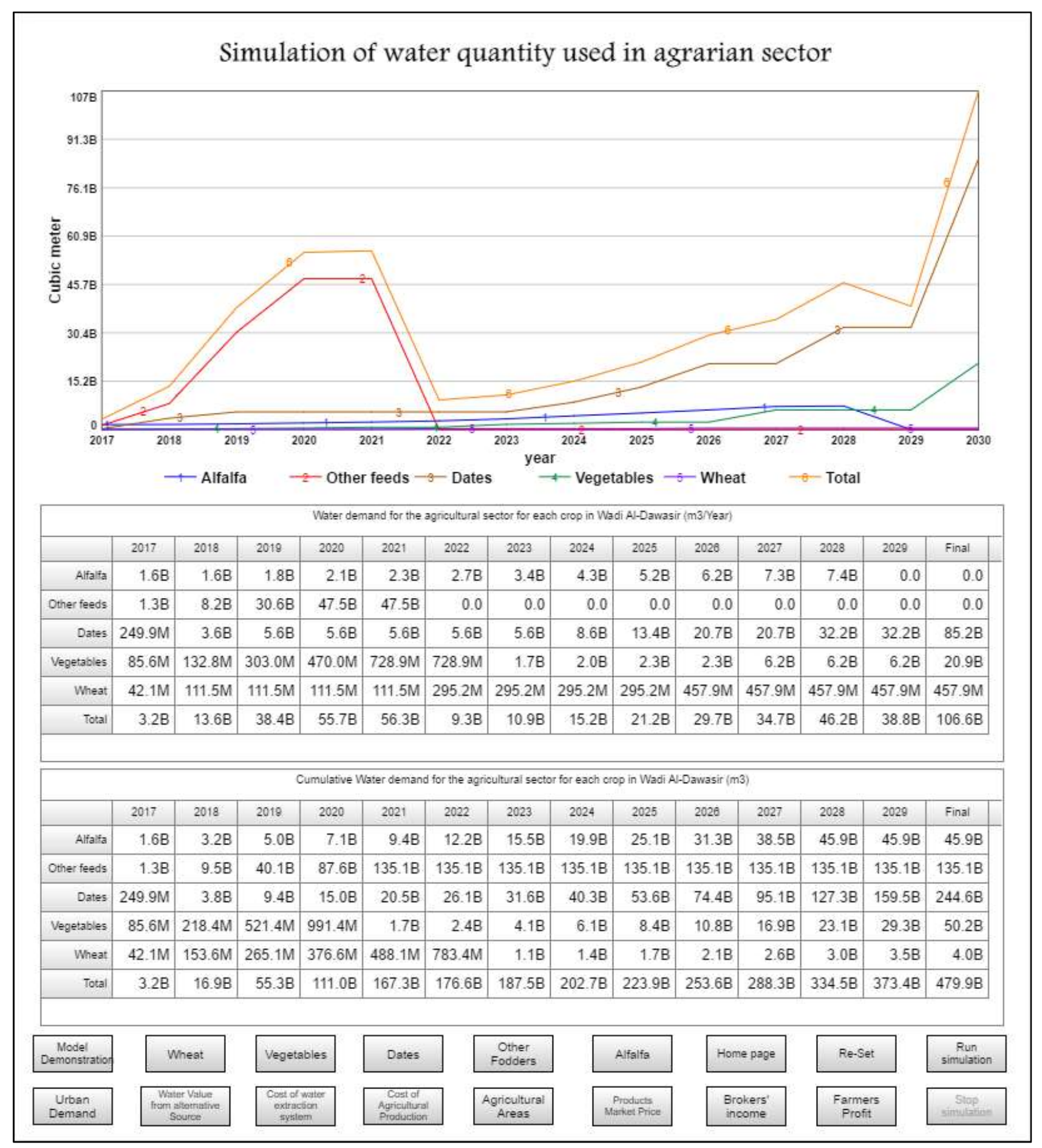

Fig. 6. A slide showing the results of simulating the amount of water used for the agricultural sector. 


\subsection{Model Verification}

The model was verified by calculating the error percentage of the resultant values of the model calculations $(\hat{Y})$ compared to the values calculated by Analysis (Y), where the error ratio was calculated using the following equation:

$$
\begin{aligned}
& \text { Error Percentage } \\
& =\left|\frac{\mathrm{Y}-\hat{\mathrm{Y}}}{\hat{\mathrm{Y}}}\right| \times 100
\end{aligned}
$$

Whereas:

Error Percentage: The error ratio of the output values of the model.

$\hat{Y}$ : Model Values.

Y: Values which calculation is obtained by Analysis.

Table 1 shows the mean of error rates in the simulation results of the annual and cumulative model outputs, where the average error rate was estimated at $0.41 \%$ in the whole model.

\subsection{The Study Scenarios}

The future of the agricultural sector in the study area is linked to regulatory, economic and environmental factors that are difficult to predict. Therefore, many scenarios have been developed on the simulation program to determine the results of each scenario (each scenario depends on different regulatory, economic and environmental conditions).

One of the most obvious factors that are expected to restructure the agricultural sector in the region is the regulatory factor where the Ministry of Environment, Water and Agriculture issued a mechanism to implement controls to stop the cultivation of green fodder in the sedimentary shelf areas (including Wadi Al-Dawasr), which is expected to be implemented by the end of 2018 (Ministry of Environment, Water and Agriculture, 2018).
It can be predicted that restructuring of the agricultural sector and agricultural areas will tend to change starting from the year 2019, and consequently, seven scenarios have been developed to predict the future of the agricultural sector, starting with baseline scenario (1), which assumes that the situation remains the same without changing the agricultural areas or cropping pattern, Scenario No. (2), which imposes non-compliance with the current policies of the water sector, also assumes the growth of cultivated areas for all crops at the rate of $1 \%$ per year.

The other scenario assumes that all fodder farms should be completely stopped and converted to other crops starting from 2019, whereas Scenario 3 assumes that all green fodder farms to be converted to wheat farms (one crop / year). Scenario (4) assumes that all green fodder farms to be converted to vegetable farms (cultivating one crop / year), Scenario (5) assumes that all green fodder farms to be converted to vegetable farms (cultivating two crops / year), (and scenario (6) assumes to convert the green fodder farms (in equal bases) to wheat farms (cultivating one crop / Year) and vegetables farms (cultivating one crop / year), and finally scenario (7) assumes to convert green fodder farms (in equal bases) to wheat farms (cultivating one crop / year) and vegetables (cultivating two crops / year).

\section{Results and Discussion}

All scenarios depend on the persistence of the agricultural area during the study period (2017-2030) with a total of 124.5 thousand hectares, except for Scenario No. 2, which is estimated to reach 141.5 thousand hectares in 2030. Agricultural areas will increase by $1 \%$ annually (see Fig. 7 and Table 2).

The results showed that the baseline scenario will consume approximately 45.4 billion cubic meters of water for the entire study period (2017-2030). The results showed 
that Scenario No. (2) is the most water consuming at the rate of 48.5 billion cubic meters for the entire study period. Scenarios $(3,4,6)$ are the least water consuming at about 24.5 billion cubic meters for the entire study period (see Fig. 8 and Table 2).

The value of the quantity of accumulated water consumed in the agricultural sector for the period (2017-2030) can be Estimate their value by assuming its transfer to the residential sector and estimating the number of people to be satisfied with this water where the average per capita consumption of water is 22 liters / day / person (Gesellschaft and Dornier, 2010 c). The results showed that the quantity of water used in the agricultural sector for the baseline scenario is estimated to be sufficient for 40.4 million people per year throughout the study period (2017-2030). The estimated water consumption in the second scenario is enough to cover the demand for approximately 43 million people per year throughout the study period. Lowest water consumption $(3,4,6)$ It is estimated that the water consumed in the agricultural sector will be sufficient for approximately 21.8 million people per year throughout the study period (2017-2030) (see Fig. 9 and Table 2).

The study assumed that the estimation of the opportunity cost of water is another tool for measuring the value of groundwater by estimating the cost of obtaining to water from an alternative source (the price of water provided by the National Water Company, which was produced from water desalination projects) (National Water Company 2018), while assuming inflation and price stability .Through this tool, the results of the study scenarios can be compared. The results showed that the opportunity cost of water cumulatively consumed during the study period (2017-2030) for Scenario (2) is estimated at about 291.1 billion riyals while baseline scenario (1) is estimated at about
272.7 billion riyals, while scenarios $(3,4,6)$ Estimated the alternative cost at about 147 billion riyals, which is the lowest.

To address the problem more thoroughly, it was necessary to highlight the real cost paid by farmers against water supply for the entire study period (2017-2030) while assuming inflation and price stability, as this cost does not exceed 8.6 billion riyals for the baseline scenario and does not exceed only 9.2 billion for scenario (2) and the cost paid by farmers to access water goes down to only 6.4 billion riyals of scenario (3) (this difference is due to the difference in cultivated crops, irrigation methods and water extraction). Consequently, the real costs of groundwater extraction are very low when compared to the opportunity cost or the number of people who can benefit from this water if converted to the residential sector (see Fig. 10 and Table 2).

By comparing the cumulative market value of the agricultural sector products (including the cost of agricultural production, the profits of farmers with the intermediaries income while assuming inflation and price stability), the estimated cumulative market value of the baseline scenario is 63.8 billion SR and this figure will increase to 68.2 billion SR for scenario (2). These figures are relatively low if we compare them with the cumulative market value of agricultural sector products for scenario (5), which is estimated to exceed 543.9 billion SR, the highest market value of agricultural products in the study scenarios (See Fig. 11 and Table 2).

This is attributed to the fact that this scenario depends on the replacement of green fodder crops with vegetable farms (two crops a year) as vegetable crops which generate a very high income for intermediaries, as estimated in scenario (5) at about 403.4 billion riyals, while farmers' profits did not exceed 83.5 billion riyals (Fig. 12 and Table 2). 
Table 1. The error percentages of the results of model simulation of the annual and cumulative outputs.

\begin{tabular}{|l|c|c|}
\hline \multicolumn{1}{|c|}{$\%$ Error } & Cumulative & Time series \\
\hline Population simulation & $0.00 \%$ & $0.00 \%$ \\
\hline Agricultural areas change simulation & $0.00 \%$ & $0.00 \%$ \\
\hline Agricultural costs simulation & $1.07 \%$ & $1.02 \%$ \\
\hline Farmers profits simulation & $1.07 \%$ & $1.02 \%$ \\
\hline Brokers income simulation & $1.07 \%$ & $1.02 \%$ \\
\hline Agricultural products price simulation & $1.07 \%$ & $1.02 \%$ \\
\hline Agrarian sector water demand simulation & $0.00 \%$ & $0.00 \%$ \\
\hline Effect of agrarian sector water transfer to urban sector & $0.00 \%$ & $0.00 \%$ \\
\hline Cost of groundwater extraction system & $0.00 \%$ & $0.00 \%$ \\
\hline $\begin{array}{l}\text { Water cost simulation in comparison with alternative } \\
\text { opportunity cost }\end{array}$ & $0.00 \%$ & $0.00 \%$ \\
\hline Average error percentage in the model & $0.43 \%$ & $0.41 \%$ \\
\hline
\end{tabular}

Table 2. Simulation results for the study area for the period (2017-2030).

\begin{tabular}{|c|c|c|c|c|c|c|c|c|}
\hline \multirow{2}{*}{ variables estimated for the study area $(2017-2030)$} & \multirow{2}{*}{ Unit } & \multicolumn{7}{|c|}{ Study Senarios } \\
\hline & & 1 & 2 & 3 & 4 & 5 & 6 & 7 \\
\hline Agricultural areas in $2030 \mathrm{G}$ & Thousand (Ha) & 124.5 & 141.7 & 124.5 & 124.5 & 124.5 & 124.5 & 124.5 \\
\hline Accumulated water quantities used in the agrarian sector & Billion (cubic M) & 45.4 & 48.5 & 24.6 & 24.5 & 39 & 24.6 & 32.3 \\
\hline $\begin{array}{l}\text { The number of people annually satisfied with the water used in } \\
\text { the agricultural sector (when converting agrarian water to urban sector). }\end{array}$ & $\begin{array}{l}\text { Million } \\
\text { (person)/Yr. }\end{array}$ & 40.4 & 43.1 & 21.9 & 21.8 & 34.7 & 21.9 & 28.8 \\
\hline Cumulative opportunity cost of groundwater used in the agrarian sector & Billion (SR) & 272.7 & 291.1 & 147.7 & 147.1 & 234.2 & 147.4 & 194.1 \\
\hline Cumulative cost of groundwater extraction system used in the agrarian sector. & Billion (SR) & 8.6 & 9.2 & 6.4 & 8.3 & 14.3 & 7.4 & 10.5 \\
\hline Cumulative market price of the agrarian sector products & Billion (SR) & 63.8 & 68.2 & 52.9 & 283.5 & 543.9 & 168.1 & 307.7 \\
\hline Cumulative profits for farmers in the agrarian sector & Billion (SR) & 18 & 19.2 & 12.7 & 46.3 & 83.5 & 29.5 & 49.4 \\
\hline Cumulative income for trade brokers in the agrarian sector & Billion (SR) & 23.5 & 25.1 & 22.2 & 205 & 403.4 & 113.6 & 219.9 \\
\hline Cumulative cost of the agrarian sector products & Billion (SR) & 22.3 & 23.8 & 18 & 32.1 & 57.1 & 25.1 & 38.4 \\
\hline
\end{tabular}

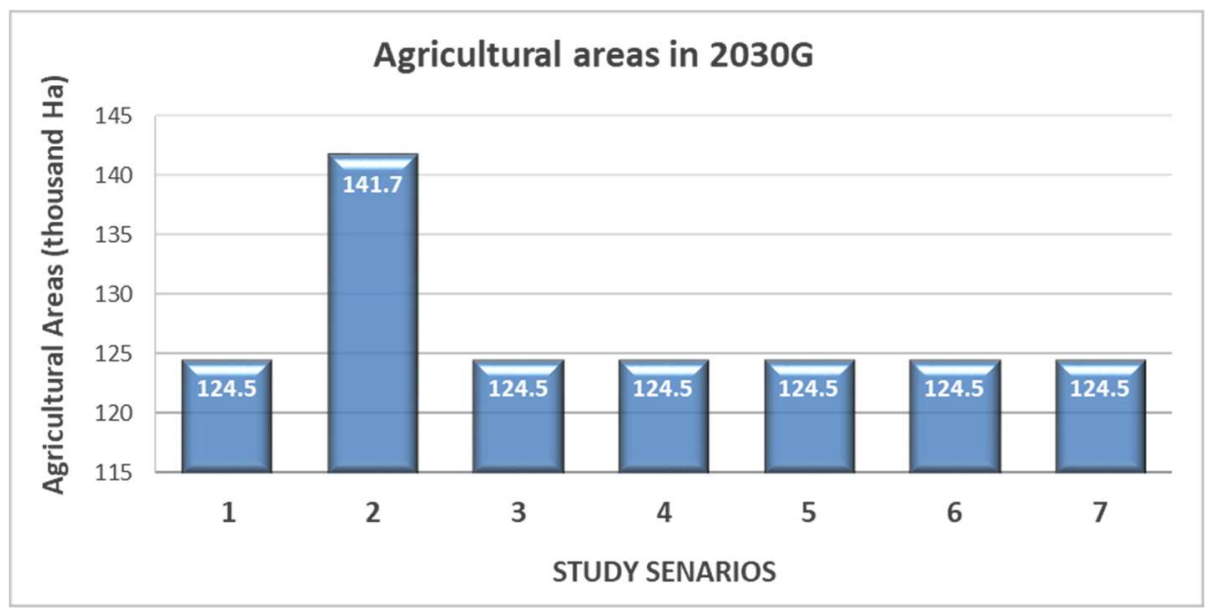

Fig. 7. Estimation of agricultural areas for the year 2030 for each scenario. 


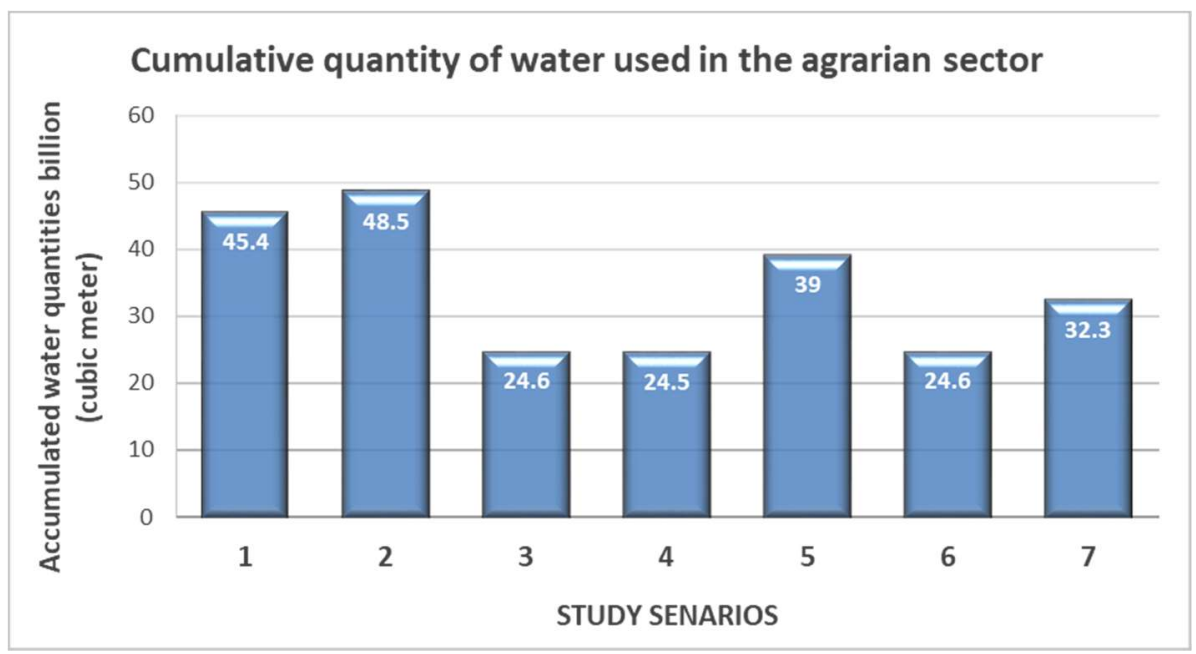

Fig. 8. Estimation of the cumulative quantity of water used in irrigation for the agricultural sector for each scenario.

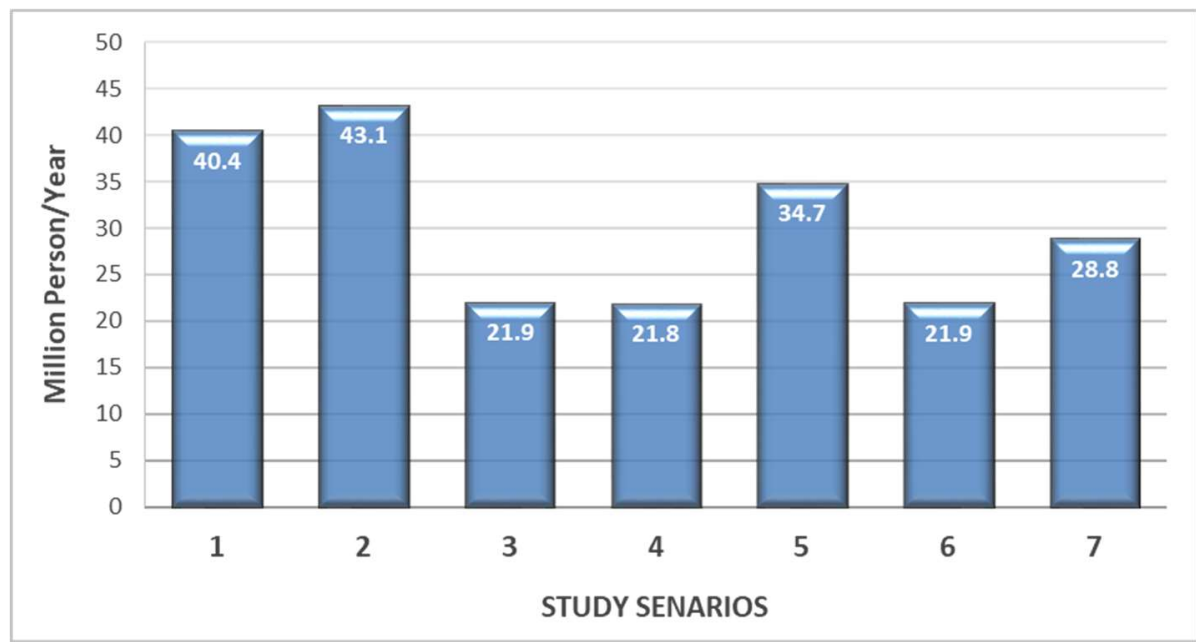

Fig. 9. Estimation of The number of population to be satisfied with the irrigation water assuming its transfer to the residential sector for each scenario.

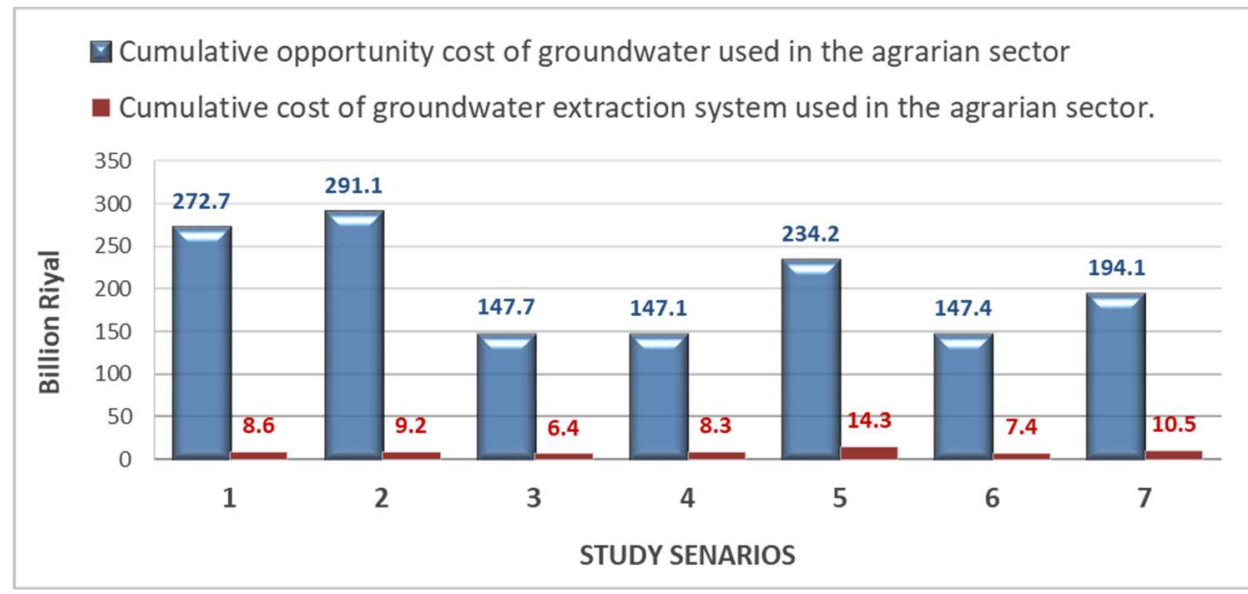

Fig. 10. Estimation of cumulative values of the opportunity cost of groundwater and the cost of groundwater extraction system used in the agricultural sector (for each scenario). 


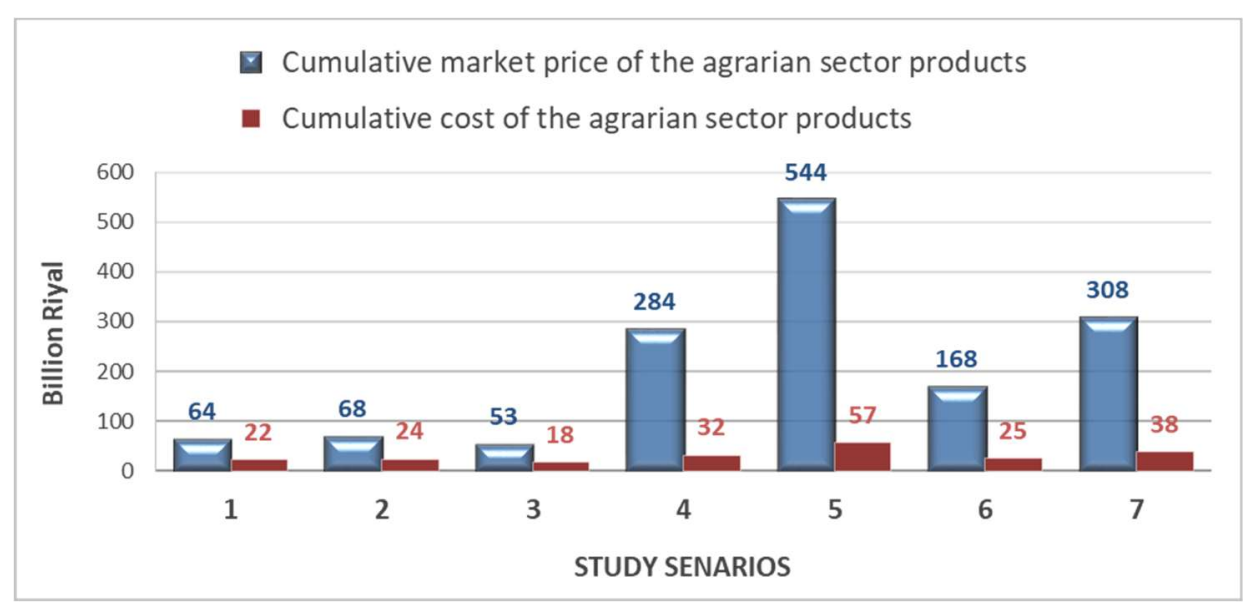

Fig. 11. Estimation of cumulative values of the cost of agricultural production and the market Price of agricultural sector products per each scenario.

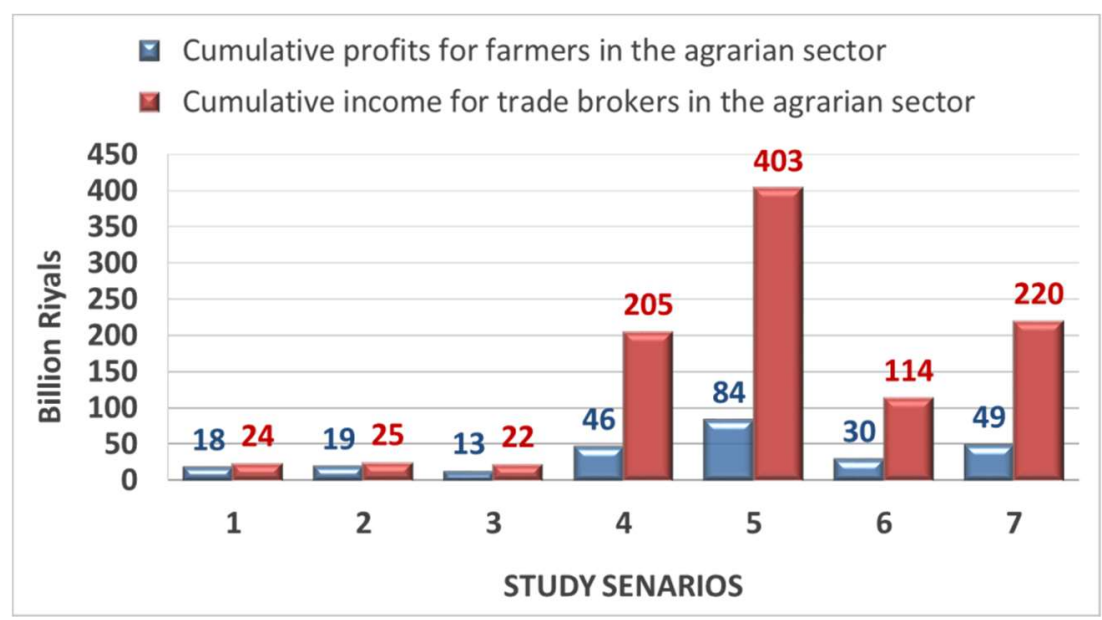

Fig. 12. Estimation of cumulative values of farmers' profits and income of trading intermediaries in the agricultural sector (per each scenario).

\section{Conclusion}

A System Dynamics Modelling to search for optimal solutions for the economic efficiency of groundwater use and to achieve water and agriculture sustainability in the Wadi Al-Dawasir region has been developed. This model is designed such that it can be applied to any area in the Kingdom of Saudi Arabia. Stella Software was utilized for the model built.

The current study has proposed seven scenarios (each scenario includes a set of regulations and variables) to be introduced into the model and studying its results for the period
(2017-2030). These scenarios were designed to study the anticipated effects of the decision of the Ministry of Environment, Water and Agriculture to organize the agricultural practices and stop the cultivation of fodder crops in Wadi Al-Dawasir area.

The results of Wadi Al-Dawasir area simulation showed that the continuation of agricultural areas and structures on its present day status until 2030 will lead to the depletion of approximately 45.4 billion cubic meters of water, and the figure could reach 48.5 billion cubic meters of water if the agricultural areas expand by $1 \%$ annually. 
But the implementation of the decision to stop the cultivation of fodder crops will reduce the cumulative depletion of water to 24.5 billion cubic meters if farmers replaced the green fodder crops with wheat or vegetables, and farmers are being compelled to cultivate a single crop in the year. Consequently, the current study arrived at that the cumulative depletion difference, if the decision were to be applied, will be at 21 billion cubic meters of water for the study period which is sufficient to cover the needs of 18.6 million people per year in the residential sector throughout the study period. The cost of alternative opportunity for water which can be conserved through the activation of stopping of the cultivation of green fodders crops resolution, is estimated at 126 billion riyals throughout the study period.

With the exclusion of the scenarios that assume to allow farmers to grow more than one crop in a year, the results showed that transfer from green fodder to vegetable cultivation (Scenario 4) will achieve the higher market value of agricultural products, with cumulative market value of agricultural products estimated at 283.5 billion SR for the entire period until 2030 .

However, the lion's share of the market value of vegetable products will be directed to trade intermediaries where their cumulative income in Scenario (4) was estimated at 205 billion SR compared to 46.3 billion SR estimated for cumulative farmers' profits for the whole study period. The researcher has accounted this to the presence of an extensive series of commercial intermediaries between the farmer and the consumer. This series goes through several business deals which impose profit for mediators in each deal.

The researchers argue that the transfer from fodder to vegetable farming, compelling farmers to grow a single crop in a year, which is the least water-consuming scenario and offers higher value agricultural products than other options while maintaining the same cultivated areas. The researchers also believe that the agricultural sector needs to be organized in regard of the marketing sector as the commercial intermediaries capture a very high share of profits compared to farmers, the organization of the marketing process will regulate the supply and demand process and enhance the profits of the farmers and keep them willing to respond to the parties calling for water conservation through installation of sophisticated irrigation systems leading to water saving and producing higher quality crops.

\section{References}

Alhassan, A.A., McCluskey,A., Alfaris, A. and Strzepek, K. (2015) Scenario Based Regional Water Supply and Demand Model: Saudi Arabia as a Case Study, International Journal of Environmental Science and Development, $7: 46-51$

Abdelfattah E. H. (2013) Discovering Statistical Analysis and Bootstrap using IBM-SPSS, Jeddah, Khawarizm Acadenic

Cheng, Q. and NiBin, C. (2011) System dynamics modeling for municipal water demand estimation in an urban region under uncertain economic impacts, Journal of Environmental Management, 92: 1628-1641.

Canada Centre for Remote Sensing (2015) Fundamentals of Remote Sensing, Canada.

Elhag, M. and Bahrawi, J. A. (2017) Realization of daily evapotranspiration in arid ecosystems based on remote sensing techniques, Geosci. Instrum. Method. Data Systems, 6: 141-147.

Forrester, J. W. (1961) Industrial Dynamics, Waltham, MA: Pegasus Communications, 464.

Ford, A. (2010) Modeling the Environment ,Second Edition, Island Press, United States of America.

Gesellschaft für Technische Zusammenarbeit and Dornier Consulting $(2010$ a), detailed studies of the water resources of the aquifer and the aquifers above it (main report), Volume 1, Department of Development Water Resources in the Ministry of Environment, Water and Agriculture.

Gesellschaft für Technische Zusammenarbeit and Dornier Consulting (2010 b), a detailed study of the water resources of Al-Wajid and the water-bearing aquifers above it (Water Demand for Agriculture), Volume 6, 
Department of Development Water Resources in the Ministry of Environment, Water and Agriculture.

Gesellschaft für Technische Zusammenarbeit and Dornier Consulting $(2010 \mathrm{c})$, a detailed studies of the water resources of Al Wajid aquifer and the water-bearing aquifers above it (Demand for Domestic and Industrial Water and the Preparation of the Use of Wastewater), Volume 7 , Water Resources Development Department, Ministry of Environment, Water and Agriculture.

Ministry of Environment, Water and Agriculture (2013) Agricultural Crops Areas for the Cities and Governorates of the Kingdom of Saudi Arabia for the Period 2000-2013.

LANDSAT-8 (2018) Satellite image ‘from web site: www.earthexplorer.usgs.gov.

Ministry of Environment, Water and Agriculture (2018), Mechanism for the Implementation of the Regulations for the Stop of Green Fodder Crops issued by the Council of Ministers Resolution No. (39), from the website: https: //www.mewa. gov.sa/ar.

National Water Company (2018), Information about tariff, from:

https://www.nwc.com.sa/Arabic/Pages/NewTarrifCalculat or.aspx, Access date, January 21, 2018.

Ouda, O.K.M.(2013) Towards Assessment of Saudi Arabia Public Awareness of Water Shortage Problem, Journal of Resources and Environment, 3: 10-13.

Zhi, L., Chunhui, L., Xuan, W., Cong, P., Yanpeng, C. and Weichen, H. (2018) A hybrid system dynamics and optimization approach for supporting sustainable water resources planning in Zhengzhou City, China, Journal of Hydrology, 556: 50-60. 
بناء نموذج نظام دينامبكي لتحقيق الكفاءة الاقتصادبة المثنلى من استخدام المياه الجوفية، در اسة تطبيقية على منطقة و ادي الدو اسر بالمملكة العربية السعودية

عبد العزيز محمد القرعاوي، و أحمد سامي قميص، و جلال محمد باصهي، و محمد إبراهيم (السعود " قسم علوم وإدارة مولرد المياه، كلية الأرصاد والبيئة وزراعة المناطق الجافة، جامعة الملك عبد العزبز، جدة، و" وزلرة البيئة والمياه والزراعة، المملكة العربية السعودية ولية

Alqarawy86@gmail.com

المستخلص. تم بناء نموذج نظام ديناميكي مائي اقتصادي زراعي لدراسة الحلول المثلى العلى

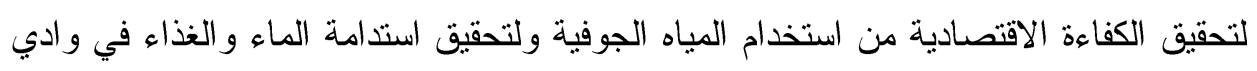

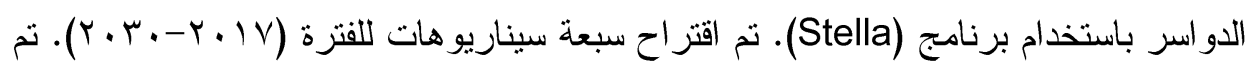
بناء هذه السيناريوهات لدراسة الآثار المتوقعة من قرار الحكومة بايقاف زراعة اعة الأعلاف

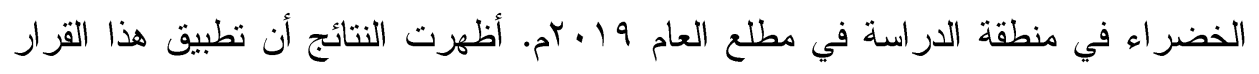

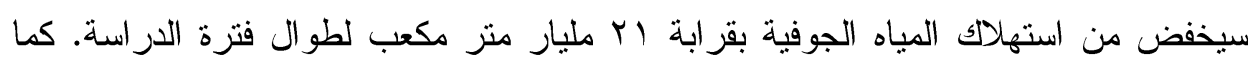
أظهرت النتائج أن استبدال زراعة الأعلاف الخضراء بالخضراوات هو السيناريو الأمثل لتحقيق الكفاءة الاقتصادية الأعلى من استخدام المياه الجوفية في منطقة الدراسة. الكلمات الدفتاحية: النظام الديناميكي، و ادي الدواسر، مياه الري، قيمة المياه الجوفية. 
